https://doi.org/10.17816/MAJ191S176-78

\title{
NEUROIMMUNE MECHANISMS OF COGNITIVE IMPAIRMENT AT AFFECTIVE DISORDERS
}

\author{
B.G. Goldin ${ }^{1,2}$
}

${ }^{1}$ Federal State Budgetary Educational Institution of Higher Professional Education

"Novosibirsk State Pedagogical University", Novosibirsk, Russia;

${ }^{2}$ Federal State Budgetary Educational Institution of Higher Education

"Novosibirsk State Medical University", Novosibirsk, Russia

\section{НЕЙРОИММУННЫЕ МЕХАНИЗМЫ КОГНИТИВНОЙ НЕДОСТАТОЧНОСТИ ПРИ АФФЕКТИВНЫХ РАССТРОЙСТВАХ}

\author{
Б.Г. Гольдин
}

ФГБОУ ВПО «Новосибирский государственный педагогический университет», Новосибирск;
ФГБОУ ВО «Новосибирский государственный медицинский университет», Новосибирск

The aim of this study was the identification of the neuroimmune mechanisms of cognitive impairment on the basis of investigation of an of cognitive disorders association with functional activity of blood mononuclear cells and the synthesis of tumor necrosis factor $-\alpha(\mathrm{TNF}-\alpha)$ in patients with affective disorders in the form of depressive reactions and depression.

TNF- $\alpha$ expression level in blood mononuclear cells of patients conducted with using the reverse transcriptase polymerase chain reaction method. The proliferative activity of blood mononuclear cells was investigated by a standard method based on the inclusion of a radioactive label. Cognitive function was assessed on the basis of perception, memory, praxis, speech, and control function. The severity of affective symptoms was measured by the Hamilton scale. It was found that patients with depressive reactions were characterized by the mild non-elemental cognitive impairment; while, in patients with depression, more severe non-elemental cognitive impairments in the form of decreased attention, memory, and daily activity were observed. In patients with affective disorders in the form of depression, an increase in the synthesis of TNF- $\alpha$ in blood mononuclear cells was detected, both an increase of the expression frequency of its gene and an increase in mRNA level, as well as an increase of the proliferative activity of blood mononuclear cells, which indicates the presence of immune system dysfunction in this category of patients.

Thus, in patients with depression, activation of the TNF- $\alpha$ synthesis in blood mononuclear cells occurs: an increase in the frequency of its expression and an increase of the level of mRNA; these changes are accompanied by the increasing of immune cells functional activity and moderate non-delicate cognitive disorder in the form of cognitive impairment.

Keywords: cognitive impairment; affective disorders; tumor necrosis factor $\alpha$; blood mononuclear cells.

Целью настоящего исследования было выявление нейроиммунных механизмов формирования когнитивной недостаточности у больных с аффективными расстройствами в форме депрессивных реакций или депрессии на основании исследования функциональной активности иммунных клеток и уровня экспрессии фактора некроза опухолей $\alpha$ в мононуклеарных клетках крови больных методом обратно - транскриптазной полимеразной цепной реакции. Пролиферативную активность мононуклеарных клеток крови исследовали стандартным методом, по включению радиоактивной метки. Когнитивную функцию оценивали на основании оценки восприятия, памяти, праксиса, речи, функции управления. Выраженность аффективной симптоматики измеряли по шкале Гамильтона. Было установлено, что больные с депрессивными реакциями характеризовались легкими недементными когнитивными нарушениями; в то время, как у больных депрессией наблюдались более тяжелые недементные когнитивные нарушения в виде снижения внимания, памяти, повседневной активности. У больных с аффективными расстройствами в форме депрессии было выявлено повышение синтеза ФНО $-\alpha$ в мононуклеарных клетках крови, как увеличение частоты экспрессии его гена, так и повышение уровня мРНК, а также увеличение пролиферативной активности мононуклеарных клеток крови, что свидетельствует о наличии дисфункции иммунной системы у данной категории больных.

Ключевые слова: когнитивная недостаточность; аффективные расстройства; фактор некроза опухолей $\alpha$; мононуклеарные клетки крови.

Introduction. Changes in the immune system functioning are an important link in the pathogenesis of a number of organic disorders of the nervous system and psyche - multiple sclerosis, schizophrenia, bipolar disorder, affective disorders, autism [1-4]. A high degree of comorbidity with autoimmune, infectious and chronic inflammatory diseases, detected in patients with mental disorders, confirms the hypothesis of the presence of com- mon immune-mediated mechanisms of pathogenesis [5, 6]. It has been established that at affective and non-affective mental disorders, the monocytemacrophage immunity is activated, the expression of pro-inflammatory genes is increased, followed by the evaluation of the pro-inflammatory cytokines concentration in serum, accompanied by the prevalence of T-type I helpers and activation of microglia in the brain [7]. The aim of this study was 
the identification of the neuroimmune mechanisms of cognitive impairment on the basis of investigation of an of cognitive disorders association with functional activity of blood mononuclear cells and the synthesis of tumor necrosis factor $-\alpha(\mathrm{TNF}-\alpha)$ in patients with affective disorders in the form of depressive reactions (DR) and depression (D).

Material and methods. 17 patients ( 8 males and 9 females) with affective disorder in a form of $\mathrm{D}$ and 26 patients (12 males and 14 females) with DR in age of 26-45 years have been included into investigation. 35 healthy volunteers $(20$ males and 15 females in the age of 34-56 years) were the control group. Peripheral blood mononuclear cells (BMC) were isolated by the Ficoll density gradient $1,077 \mathrm{~g} / \mathrm{ml}$ centrifugation of venous blood. Then the BMC were incubated in HEPES - buffered RPMI - 1640, supplemented with gentamycin, L - glutamine, non-essential amino acids during 72 hours in $\mathrm{CO}_{2}$ incubator at $37{ }^{\circ} \mathrm{C}$ and $5 \% \mathrm{CO}_{2}$. The BMC proliferative activity was estimated in unstimulated and phytogemagglutinin (FGA)-stimulated cell cultures by the standard method of $\mathrm{H}^{3}$-thymidin incorporation. For the estimation of TNF- $\alpha$ expression, BMC were washed thoroughly in supplemented RPMI - 164 right after the Ficoll density gradient centrifugation. Examination of TNF- $\alpha$ gene expression has been conducted by the method of reverse - transcriptase polymerase chain reaction. Isolation of the total RNA was performed by the method of phenol extraction, with using of the VectoRNA - extraction test - system (Vector - Best, Novosibirsk). The obtained DNA was amplified in a "Terzik" programmable amplifiers, (DNA technology, Moscow), using the oligonucleotide primer pairs for the TNF- $\alpha$ gene. The obtained cDNA fragments were analyzed in $2 \%$ agarose gel with the addition of $0.00001 \%$ bromide ethidium (VectoDNA - EF, Vector - Best, Novosibirsk). Samples with a cDNA band in the gel corresponding to the expected amplicon size were considered as positive. The cognitive function in the studied groups was assessed on the basis of perception, memory, praxis, speech, and control functions. The severity of affective disorders symptoms was determined by the Hamilton scale. Statistical data processing was performed by using of the STATISTICA v.10.0 software package
(StatSoft, USA). The statistical significance of the differences estimated by the Kruskall-Wallis criterium at $p<0.05$. The correlation between parameters estimated by the McNemar criterium.

Results and discussion. Clinically all patients included in the study showed signs of affective reactions in the form of DR or D. The group of patients with depression characterized by a mood disorder, mainly in the direction of oppression, mood changes were accompanied by a decrease in the general level of emotional and physical activity, and tended to be repeated. A group of patients with depressive reactions characterized by the development of affective symptoms in all cases in response to physical or psychological stress, in a combination of a reduced mood background with anxiety symptoms, vegetative disturbances in the form of tachycardia, skin hyperemia, and hyperhidrosis. Since cytokine synthesis is one of the most important indicators of the functional activity of immunocompetent cells, we studied the frequency and level of expression of the TNF $\alpha$ gene in BMC of healthy volunteers and patients with affective reactions. It was found that the frequency of TNF- $\alpha$ gene expression in BMC of patients with depression was significantly higher than at healthy volunteers and patients with DR $(83.3 \%, 2.9 \%$ and $27.0 \%$, respectively, $p<0.05)$. The TNF- $\alpha$ mRNA level exceeds the same parameters of healthy volunteers and patients with depressive reactions. The level of mitogen-induced BMC proliferation at depressive patients also exceeds the parameters of healthy volunteers and patients with depressive reactions $(34595(32461 ; 37288) \mathrm{imp} / \mathrm{min}$, $p<0.05,22935 \quad(19567 ; 25611) \mathrm{imp} / \mathrm{min}$, and $18989(15354 ; 22675) \mathrm{imp} / \mathrm{min}$, respectively). When analyzing the relationship between the TNF- $\alpha$ expression and cognitive impairment in patients with depression, the dependence of the frequency of TNF- $\alpha$ expression and the severity of cognitive impairment $(p=0.0003$, (McNemar) ) was established.

Conclusion. Thus, in patients with depression, activation of the TNF- $\alpha$ synthesis in blood mononuclear cells occurs: an increase in the frequency of its expression and an increase of the level of mRNA; these changes are accompanied by the increasing of immune cells functional activity and moderate non-delicate cognitive disorder in the form of cognitive impairment.

\section{References}

1. Khandaker GM, Cousins L, Deakin J, et al. Inflammation and immunity in schizophrenia: implications for pathophysiology and treatment. Lancet Psychiatry. 2015;2(3):258-270.

2. Leboyer M, Berk M, Yolken RH, et al. Immuno-psychiatry: an agenda for clinical practice and innovative research. BMC Med. 2016;14:173. https://doi.org/10.1186/s12916-016-0712-5.

3. Goldina IA, Markova EV. Neiroimmunnye mehanismy patogeneza rasseyannogo sclerosa. Krasnoyarsk: Nauchno-innovacionnyi centr; 2018. 150 p. (In Russ.). https://doi.org/10.12731/978-5-906314-89-5.

4. Smagin AA, Goldina IA, Gaidul KV. Issledovanie proliferativnoi aktivnosti mononuclearnyh kletok krovi bolnyh rasseyannym sklerozom pri vozdeistvii peptida regiona envelope endogennogo retrovirusa cheloveka HERV-E $\lambda$ 4-1. Medicinskaya immunologia. 2014;16(3):247-256. (In Russ.).

5. Rozenblat JD, Levey D, Le-Niculescu H, et al. Psychiatric blood biomarkers: avoiding jumping to premature negative or positive conclusions. Mol. Psychiatry. 2015;20(3);286-288. 